[ARTICLE]

\title{
SCRAMBLING AND GENITIVE SUBJECTS IN MONGOLIAN
}

\author{
HideKi MAKi ${ }^{1}$, Lina BaO ${ }^{1}$, Wurigumula BaO and Megumi Hasebe ${ }^{2}$ \\ Gifu University ${ }^{1}$ and Shinshu University ${ }^{2}$
}

\begin{abstract}
This paper investigates environments of genitive subject licensing in Mongolian, and shows (i) that scrambled NPs can license genitive subjects in Mongolian, (ii) that genitive subject licensing takes place at LF in Mongolian, suggesting that scrambling does not involve obligatory LF undoing, (iii) that both Mongolian and Japanese obey the same conditions on genitive subject licensing, and the differences between the two languages arise from the environments in which the adnominal form of a predicate may appear, and (iv) that there are (at least) two types of languages in the world with respect to genitive subject licensing.*
\end{abstract}

Keywords: adnominal, genitive subject, Japanese, Mongolian, scrambling

\section{Introduction}

Research on genitive subjects in Japanese originates in Harada (1971), and since then, it has produced fruitful results. See Miyagawa (1993, 2011, 2012, 2013), Watanabe (1996), Hiraiwa (2001) and Ochi (2001), among others. This paper investigates the distribution of genitive subjects in the Khorchin dialect of Mongolian, an Altaic language, spoken in Inner Mongolia (Mongolian, hereafter), and elucidates the mechanism of genitive subject licensing in the language. The key finding of this research is the fact that Mongolian allows genitive subjects not only in sentential modifiers to nouns, but also in independent clauses that involve scrambling. It has not been reported in the generative literature that scrambling saves genitive subjects. We then discuss what this finding may suggest for the theory of (Mongolian) syntax.

* We would like to thank Jessica Dunton, Hanshamuga, Keiichiro Kobayashi, Naohiko Kurokawa, Fumikazu Niinuma, Masako Maeda, Yuta Sakamoto, Michael Sevier, three anonymous $E L$ referees and two anonymous $L I$ referees for their valuable comments on an earlier version of this paper. All errors are our own.

English Linguistics 33: 1 (2016) 1-35 - 1-

(C) 2016 by the English Linguistic Society of Japan 
The structure of this paper is as follows. Section 2 provides fundamental syntactic properties of Mongolian as the background to subsequent sections. Section 3 presents new data on genitive subjects in Mongolian. Section 4 discusses what the findings in this paper might suggest for the theory of (Mongolian) syntax, and Section 5 concludes the paper.

\section{Background}

Mongolian is a head-final language that allows genitive subjects and scrambling, which will be briefly reviewed below. First, in Mongolian, genitive subjects are disallowed in simple sentences, as shown in (1), but both nominative and genitive subjects are allowed, when they appear in relative clauses, as shown in (2). ${ }^{1,2}$

(1) Öčügedür Ulayan- $\varnothing / *-u \quad$ nom- $\varnothing$ qudaldun-ab-čai. yesterday Ulagan-Nom/-Gen book-Acc buy-take-Past.Con 'Ulagan bought a book yesterday.'

(2) Öčügedür Ulayan-ø/-u $t$ qudaldun-abu-ysan/*-ab-čai yesterday Ulagan-Nom/-Gen buy-take-Past.Adn/-take-Past.Con nom-bol ene nom. book-Top this book

'The book which Ulagan bought yesterday is this book.'

Note that in Mongolian, while a relative clause requires the predicate to be in the adnominal form, as shown in (2), a simple clause requires the predicate to be in the conclusive form, as shown in (1), but requires it to be in the adnominal form when a sentence-final particle follows it, as shown in (3).

1 The abbreviations used in this paper are as follows: $3=$ third person, Acc $=$ accusative, $\mathrm{Adn}=$ adnominal, Con $=$ conclusive, Cont $=$ continuous, $\mathrm{E}=$ ergative, $\mathrm{Foc}=$ focus, Fut $=$ future, Gen $=$ genitive, Imp $=$ imperative, In $=$ infix, Inf $=$ infinitival, Loc $=$ locative, $\mathrm{Nml}=$ nominalizer, $\mathrm{Nom}=$ nominative, $\mathrm{Obl}=$ oblique, Past $=$ past, Perf $=$ Perfective, $\mathrm{Pl}=$ plural, $\mathrm{PoP}=$ possessive pronoun, $\mathrm{Pres}=$ present, $\mathrm{Prt}=$ sentence-final particle, $\mathrm{Q}=$ wh-question, $\mathrm{Sg}=$ singular, Top $=$ topic, $\mathrm{Unm}=$ unmarked case and $\mathrm{YNQ}=$ yes/ no-question.

2 For expository purposes, the gap in a relative clause is represented as a trace rather than a resumptive pronoun. The choice between these does not affect the argument in the paper. 

(3) Öčügedür Ulayan- $\varnothing$ nom- $\varnothing$
yesterday Ulagan-Nom book-Acc
qudaldun-abu-ysan/*-ab-čai-siu.
buy-take-Past.Adn/-take-Past.Con-Prt
'Ulagan bought a book yesterday.'

The sentence-final particle siu in (3) roughly corresponds to yo in Japanese, as shown in (4).

(4) Kinoo Hanako-ga hon-o kat-ta-yo.
yesterday Hanako-Nom book-Acc buy-Past-Prt
'Hanako bought a book yesterday.'

Endo (2007: 180) states that the sentence-final yo implies the speaker's emphasis in giving a piece of information to the addressee. See Kuroda (1973) and Matsuoka (2003) for details on the particle. Likewise, the question particle bui ' $Q$ ' also requires the preceding predicate to be in the adnominal form in Mongolian, as shown in (5).

(5) Öčügedür Ulayan-ø yayu- $\varnothing$ yesterday Ulagan-Nom what-Acc qudaldun-abu-ysan/*-ab-čai-bui? buy-take-Past.Adn/-take-Past.Con-Q

'What did Ulagan buy yesterday?'

Maki et al. (2010) report that genitive subjects are also allowed in a nonlocal relationship with the relative head, as shown in (6) and (7).

(6)

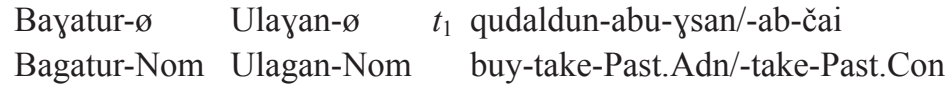

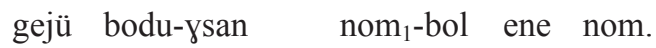

that think-Past.Adn book-Top this book 'The book which Bagatur thought [that Ulagan bought $t$ ] is this book.'

(7) Bayatur-ø Ulayan-u $t_{1}$ qudaldun-ab-ysan/*-ab-čai

Bagatur-Nom Ulagan-Gen buy-take-Past.Adn/-take-Past.Con

gejü bodu-ysan nom ${ }_{1}$-bol ene nom.

that think-Past.Adn book-Top this book

'The book which Bagatur thought [that Ulagan bought $t$ ] is this book.'

In (6), the subject in the embedded clause is marked nominative, and the predicate can be either in the adnominal form or the conclusive form. In (7), the subject in the embedded clause is marked genitive only when the predicate is in the adnominal from. Note that genitive subjects in embedded clauses need a relative head, as shown by (7) and (8). 
(8) Bayatur-ø Ulayan- $\varnothing / *-u \quad$ nom- $\varnothing$

Bagatur-Nom Ulagan-Nom/-Gen book-Acc

qudaldun-abu-ysan/-ab-čai gejü bodu-jai.

buy-take-Past.Adn/-take-Past.Con that think-Past.Con

'Bagatur thought [that Ulagan bought a book].'

Maki et al. (2011) further investigated examples with gapless prenominal sentential modifiers, as shown in (9) and (10).

(9) a. Öčügedür Ulayan-ø/*-u iniye-jei.

yesterday Ulagan-Nom/-Gen laugh-Past.Con

'Ulagan laughed yesterday.'

b. Batu-ø [öčügedür Ulayan-ø/-u iniye-gsen

Batu-Nom yesterday Ulagan-Nom/-Gen laugh-Past.Adn učir] tu soči-jai.

fact at be.surprised-Past.Con

'Batu was surprised at [the fact that Ulagan laughed yesterday].'

(10)

a. Bayatur- $\varnothing$ [öčügedür Ulayan- $\varnothing / *-u$ iniye-gsen

Bagatur-Nom yesterday Ulagan-Nom/-Gen laugh-Past.Adn

gejü] kele-jei.

that say-Past.Con

'Bagtur said [that Ulagan laughed yesterday].'

b. Batu- $\varnothing$ [Bayatur- $\varnothing$ [öčügedür Ulayan- $\varnothing / *-u$

Batu-Nom Bagatur-Nom yesterday Ulagan-Nom/-Gen

iniye-gsen gejü] kele-gsen učir] tu

laugh-Past.Adn that say-Past.Adn fact at

soči-jai.

be.surprised-Past.Con

'Batu was surprised at [the fact that Bagatur said [that Ulagan laughed yesterday]].'

(9a) is a simple sentence without a nominal head. It is grammatical with a nominative subject, but ungrammatical with a genitive subject. (9b) contains an NP with a gapless prenominal sentential modifier. It is grammatical, irrespective of whether the subject is nominative or genitive. (10a) contains a complement clause. It is grammatical when the subject in the embedded clause is nominative, but ungrammatical when it is genitive. (10b) contains an NP with a gapless prenominal sentential modifier. In contrast to (9b), it is grammatical only when the subject in the embedded clause is nominative.

The crucial difference between the grammatical sentence in (7) and the 
ungrammatical sentence with a genitive subject in (10b) is the fact that the former has a relative head with the corresponding gap in the relative clause. If genitive subject licensors were limited to relative heads with corresponding gaps alone, (9b) with a genitive subject would be incorrectly predicted to be ungrammatical. Therefore, it is necessary to assume that a nominal element is somehow involved in genitive subject licensing. Then, in order to correctly exclude (10b) with a genitive subject, while ruling in (9b) with a genitive subject, genitive subject licensing must be local in such a way that a nominal element is close enough to the genitive subject, where "close enough" needs to be precisely defined. Since the close enough relation between the outer nominal element and the genitive subject in (9b) is of the form shown in (11), Maki et al. (2011) assume that the link shown in the configuration in (11) is the close enough relation.

(11) [Sub-Gen...V-T(Adn)] N

If this is correct, the issue that immediately suggests itself is the way the genitive subject in (7) can be locally licensed by a nominal element, which does not apparently exist in the close domain. The crucial point is that (7) has a gap which is bound by the relative head, which seems to make a crucial contribution to licensing of the genitive subject in (7). Maki et al. (2011) then propose that a relation is established between a relative head and its gap $t$ by binding (c-commanding), in such a way that the nominal feature in the nominal head percolates down to $t$, as shown by the structure in (12), where the categories on the path from the nominal head to $t$ are squared.

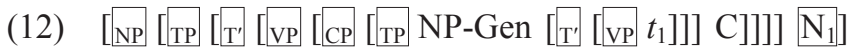

It is not implausible to assume that if a maximal projection XP has a certain feature, the head $\mathrm{X}^{0}$ also shares it with $\mathrm{XP}$ by percolation. If the squared categories in (12) on the path from the relative head to $t$ all host a nominal feature, the circled $\mathrm{C}$ in the most deeply embedded clause in (13) also hosts it, as the $\mathrm{CP}$ which it projects is among the squared categories.

(13) $\left[\mathrm{NP}_{\mathrm{NP}}\left[\mathrm{TP}_{\mathrm{TP}}\left[\mathrm{T}_{\mathrm{T}}\left[\mathrm{VP}_{\mathrm{VP}}\left[\mathrm{CP}_{\mathrm{CP}}\left[\mathrm{TP}_{\mathrm{TP}} \mathrm{NP}-\mathrm{Gen}\left[\mathrm{TT}_{\mathrm{T}}\left[\mathrm{VP}_{\mathrm{VP}} t_{1}\right]\right]\right] \mathrm{CD}\right]\right]\right] \mathrm{N}_{1}\right]\right.$

If this takes place, the local configuration with the genitive subject in the most deeply embedded clause in (13) will look like (14).

$$
\text { [Sub-Gen...V-T(Adn)] } \mathrm{C}_{[+\mathrm{N}]}
$$

Note that this is exactly parallel to the configuration in (11), where $\mathrm{N}$, instead of $\mathrm{C}_{[+\mathrm{N}]}$, is involved in genitive subject licensing. Thus, they claim that this type of mechanism is in operation in genitive subject licensing in 
Mongolian, and propose (15) based on two important approaches to genitive subject licensing in Japanese, namely, Miyagawa's (1993, 2011) D-licensing approach and Watanabe's (1996) and Hiraiwa's (2001) adnominal formlicensing approach.

(15) Conditions on Genitive Subject Licensing in Mongolian

a. A genitive subject must be c-commanded by a nominal element in a local domain.

b. A genitive subject must be in a local relationship with the adnominal form of a predicate.

(15a) corresponds to Miyagawa's $(1993,2011)$ D-licensing approach, and (15b) to Watanabe's (1996)/Hiraiwa's (2001) adnominal form-licensing approach. Miyagawa (1993) proposes that in Japanese, the genitive subject in a prenominal gapless clause raises into DP Spec at LF, and D checks the Case feature on the genitive subject. See also Ochi (2001) for an extension of this approach. On the other hand, Hiraiwa (2001) argues that genitive subject licensing in Japanese depends on the existence of the adnominal form of a predicate, not the functional category $\mathrm{D}$, based on the fact that there is a set of clauses allowing genitive subjects that do not involve a noun (hence, D) in Japanese, such as comparative clauses originally observed by Watanabe (1996).

Note here that not only (15a), but also (15b), is necessary for genitive subject licensing in Mongolian, because (7) would be incorrectly predicted to be grammatical with the conclusive form of the predicate in the embedded clause.

The mechanism originally proposed by Maki et al. (2011), however, needs to be revised, because, as correctly pointed out by one of the referees, it is not clear that the assignment of $[+\mathrm{N}]$ to categories with $[-\mathrm{N}]$ does not lead to any contradiction in feature value. Therefore, we revise Maki et al.'s (2011) original idea, and hypothesize that only the relevant Comp in the binding path from the relative head to its gap may host the feature $[+\mathrm{N}]$ inherited from the relative head, and can function as a licensor for genitive subjects, based on Rizzi's (1990) idea about feature specifications on functional categories. Rizzi (1990: 382) proposes that functional categories such as Comp and Infl have feature specifications made out of a combination of two binary features $[ \pm \mathrm{C}]$ and $[ \pm \mathrm{I}]$, and Comp has the feature specifications $[+\mathrm{C},-\mathrm{I}]$. What is important here is the fact that Comp does not have any feature specification regarding $[ \pm \mathrm{N}]$, so that it is not implausible to assume that it can host the feature $[+\mathrm{N}]$, as this will not cause a contradiction among the feature specifications on Comp. What is more important 
is the fact that the relevant Comp which can potentially license genitive subjects follows the adnominal form, not the conclusive form, of a predicate, which seems to indicate that the Comp at issue is as "nominal" as the adnominal form of the predicate, as a consequence of the agreement relationship between the V-I complex and Comp, which is widely observed in human language.

Second, Mongolian allows scrambling. (16b) and (17b) show that short distance scrambling and long distance scrambling are permitted, respectively. See Saito $(1985,1989,1992)$, among others, for details of scrambling.

a. Ulayan- $\varnothing$ ene nom-i biči-jei.

Ulagan-Nom this book-Acc write-Past.Con

'Ulagan wrote this book.'

b. Ene nom-i Ulayan-ø $t$ biči-jei.

this book-Acc Ulagan-Nom write-Past.Con

'This book, Ulagan wrote $t$.'
a. Bayatur- $\varnothing$
Ulayan-ø
ene nom-i
biči-gsen
Bagatur-Nom Ulagan-Nom this book-Acc write-Past.Adn gejü boduju bayina.
that think be.Pres.Con
'Bagatur thinks that Ulagan wrote this book.'
b. Ene nom-i Bayatur- $\varnothing$ Ulayan- $\varnothing \quad t$ biči-gsen
this book-Acc Bagatur-Nom Ulagan-Nom write-Past.Adn gejü boduju bayina.
that think be.Pres.Con
'This book, Bagatur thinks that Ulagan wrote $t$.'

Furthermore, scrambling can be undone in Mongolian, as shown in (18b), just as in Japanese (Saito (1989)).
a. Bayatur- $\varnothing$
[Ulayan-ø
nom-un sang-eče
ali
Bagatur-Nom Ulagan-Nom book-Gen library-from which nom-i jigele-gsen-i] mede-ne.
book-Acc check.out-Past.Adn-Acc know-Pres.Con
'Bagatur knows [which book Ulagan checked out $t$ from the library].'
b. Ali nom-i Bayatur- $\varnothing$ [Ulayan- $\varnothing$ nom-un which book-Acc Bagatur-Nom Ulagan-Nom book-Gen sang-eče $t$ jigele-gsen-i] mede-ne. library-from check.out-Past.Adn-Acc know-Pres.Con 'Which book, Bagatur knows [Q Ulagan checked out $t$ from the library].'


In (18a), the wh-phrase ali nom-i 'which book-Acc' is base-generated in an interrogative clause, where it takes scope, although in Mongolian, an interrogative clause is not followed by an overt [+Q] Comp. In (18b), the whphrase moves out of the embedded clause, and is adjoined to the sentenceinitial position, where it does not take scope. In order for it to be properly interpreted, it needs to move back to its original position at LF. Since (18b) is grammatical in Mongolian, LF undoing of scrambling actually takes place in Mongolian, just as in Japanese.

\section{Data}

Having established some relevant background, let us now examine new data that involve scrambling. (19) is a simple affirmative sentence, the predicate is in the conclusive form, and the genitive subject is not allowed.

(19) Öčügedür Ulayan-ø/*-u ene nom-i qudaldun-ab-čai. yesterday Ulagan-Nom/-Gen this book-Acc buy-take-Past.Con 'Ulagan bought this book yesterday.'

(20a) shows that the object is moved to the sentence-initial position by scrambling, and the sentence is ungrammatical with a genitive subject. (20b) shows that the object is moved to the position just in front of the subject by scrambling, and again, the sentence is ungrammatical with a genitive subject.

(20)
$\begin{array}{llll}\text { a. Ene nom-i öčügedür } & \text { Ulayan-ø/*-u }{ }^{*} t \\ \text { this book-Acc } & \text { yesterday } & \text { Ulagan-Nom/-Gen }\end{array}$ qudaldun-ab-čai.
buy-take-Past.Con
'This book, Ulagan bought $t$ yesterday.'
b. Öčügedür ene nom-i Ulayan-ø/*-u $t$
yesterday this book-Acc Ulagan-Nom/-Gen
qudaldun-ab-čai.
buy-take-Past.Con
'This book, Ulagan bought $t$ yesterday.'

Let us then examine examples with the adnominal form of a predicate. (21) has the sentence-final particle siu, which follows the adnominal form of a predicate, and the genitive subject is not allowed.
(21)
ene nom-i
qudaldun-abu-ysan-siu. yesterday Ulagan-Nom/-Gen this book-Acc buy-take-Past.Adn-Prt 'Ulagan bought this book yesterday.'

(22a) shows that the object is moved to the sentence-initial position by 
scrambling. Interestingly enough, the sentence is grammatical with a genitive subject. (22b) shows that the object is moved to the position just in front of the subject by scrambling, and again, the sentence is grammatical with a genitive subject.

$$
\begin{aligned}
& \text { a. Ene nom-i öčügedür Ulayan-ø/-u } t \\
& \text { this book-Acc yesterday Ulagan-Nom/-Gen } \\
& \text { qudaldun-abu-ysan-siu. } \\
& \text { buy-take-Past.Adn-Prt } \\
& \text { 'This book, Ulagan bought } t \text { yesterday.' } \\
& \text { b. Öčügedür ene nom-i Ulayan-ø/-u } t \\
& \text { yesterday this book-Acc Ulagan-Nom/-Gen } \\
& \text { qudaldun-abu-ysan-siu. } \\
& \text { buy-take-Past.Adn-Prt }
\end{aligned}
$$

The same pattern is observed with wh-questions. Consider the example in (23). (23) has the sentence-final particle bui 'Q,' which follows the adnominal form of a predicate, and the genitive subject is not allowed.
(23) Öčügedür Ulayan-ø/*-u yayu- $\varnothing$ qudaldun-abu- yesterday Ulagan-Nom/-Gen what-Acc buy-take-Past.Adn-Q '[Q Ulagan bought what yesterday].'

(24a) shows that the wh-phrase in the object position is moved to the sentence-initial position by scrambling. Interestingly enough, the sentence is grammatical with a genitive subject. (24b) shows that the object wh-phrase is moved to the position just in front of the subject by scrambling, and again, the sentence is grammatical with a genitive subject.
(24)
a. Yayu-yi öčügedür Ulayan-ø/-u $t$
what-Acc yesterday Ulagan-Nom/-Gen
qudaldun-abu-ysan-bui?
buy-take-Past.Adn-Q
'[Q what, Ulagan bought $t$ yesterday].'
b. Öčügedür yayu-yi Ulayan-ø/-u $t$
yesterday what-Acc Ulagan-Nom/-Gen qudaldun-abu-ysan-bui?
buy-take-Past.Adn-Q
'[Q what, Ulagan bought $t$ yesterday].'

The same pattern is also observed with subject wh-questions. (25) has a subject wh-phrase, and the genitive subject is disallowed. 
(25) Öčügedür ken-ø/*-ü ene nom-i qudaldun-abu-ysan-bui? yesterday who-Nom/-Gen this book-Acc buy-take-Past.Adn-Q 'Who bought this book yesterday?'

(26a) shows that the object is moved to the sentence-initial position by scrambling, and the sentence is grammatical with a genitive subject. (26b) shows that the object is moved to the position just in front of the subject by scrambling, and again, the sentence is grammatical with a genitive subject.

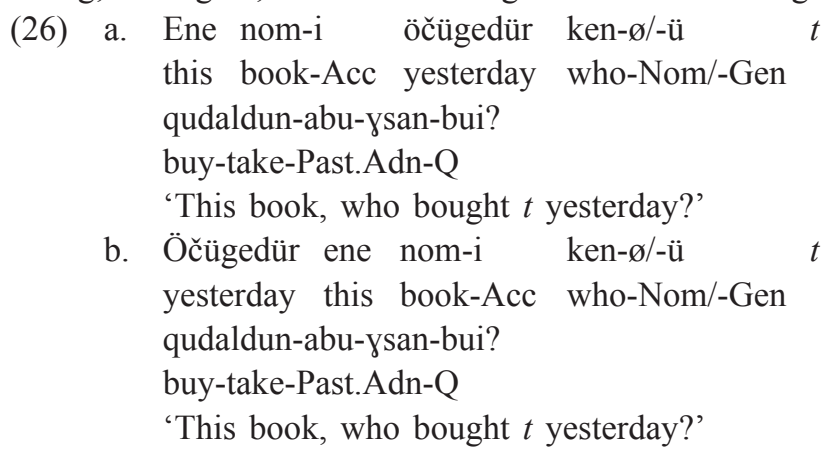

The above data clearly show that moved objects can license genitive subjects when the predicate is in the adnominal form.

Let us then examine cases where elements other than objects are scrambled. Consider the examples in (27) and (28). Both (27) and (28) have the intransitive verb ire 'to come,' which co-occurs with a goal phrase, and disallow a genitive subject.

(27) Öčügedür ken-ø/*-ü Tookyo-du ire-gsen-bui? yesterday who-Nom/-Gen Tokyo-to come-Past.Adn-Q 'Who came to Tokyo yesterday?'

(28) Öčügedür Ulayan-ø/*-u Tookyo-du ire-gsen-siu. yesterday Ulagan-Nom/-Gen Tokyo-to come-Past.Adn-Prt 'Ulagan came to Tokyo yesterday.'

In $(29 \mathrm{a}, \mathrm{b})$, the goal phrase is moved to the sentence-initial position by scrambling, and each of the sentences is ungrammatical with a genitive subject.
a. Tookyo-du öčügedür ken-ø/*-ü
$t$ ire-gsen-bui?
Tokyo-to yesterday who-Nom/-Gen come-Past.Adn-Q
'To Tokyo, who came $t$ yesterday?'
b. Tookyo-du öčügedür Ulayan- $\varnothing /{ }^{*}-\mathrm{u} \quad t$ ire-gsen-siu. Tokyo-to yesterday Ulagan-Nom/-Gen come-Past.Adn-Prt 'To Tokyo, Ulagan came $t$ yesterday.'

$(30 \mathrm{a}, \mathrm{b})$ show that the goal phrase is moved to the position just in front of 
the subject by scrambling, and again, each of the sentences is ungrammatical with a genitive subject.
a. Öčügedür Tookyo-du ken-ø/*-ü
$t$ ire-gsen-bui?
yesterday Tokyo-to who-Nom/-Gen come-Past.Adn-Q
'To Tokyo, who came $t$ yesterday?'
b. Öčügedür Tookyo-du Ulayan-ø/*-u $t$ ire-gsen-siu. yesterday Tokyo-to Ulagan-Nom/-Gen come-Past.Adn-Prt 'To Tokyo, Ulagan came $t$ yesterday.'

This indicates that a goal phrase cannot license genitive subjects in Mongolian.

The same pattern is observed with a goal phrase with a ditransitive verb. Both (31) and (32) have the ditransitive verb ügkü 'to give,' and do not allow a genitive subject.
(31) Öčügedür Bayatur-ø/*-un Ulayan-du yayu- $\varnothing$ yesterday Bagatur-Nom/-Gen Ulagan-to what-Acc ügkü-gsen-bui? give-Past.Adn-Q
'[Q Bagatur gave what to Ulagan].'
(32) Öčügedür Bayatur-ø/*-un Ulayan-du nom-ø yesterday Bagatur-Nom/-Gen Ulagan-to book-Acc ügkü-gsen-siu. give-Past.Adn-Prt
'Bagatur gave a book to Ulagan.'

In $(33 a, b)$, the goal phrase is moved to the sentence-initial position by scrambling, and each of the sentences is ungrammatical with a genitive subject.
a. Ulayan-du öčügedür Bayatur-ø/*-un $\quad t$ yayu-ø
Ulagan-to yesterday Bagatur-Nom/-Gen what-Acc ügkü-gsen-bui?
give-Past.Adn-Q
'[Q to Ulagan, Bagatur gave what $t]$.'
b. Ulayan-du öčügedür Bayatur-ø/*-un
$t$ nom- $\varnothing$
Ulagan-to yesterday Bagatur-Nom/-Gen book-Acc ügkü-gsen-siu.
give-Past.Adn-Prt
'To Ulagan, Bagatur gave a book $t$.'

(34a, b) show that the goal phrase is moved to the position just in front of the subject by scrambling, and again, each of the sentences is ungrammatical with a genitive subject. 
(34)

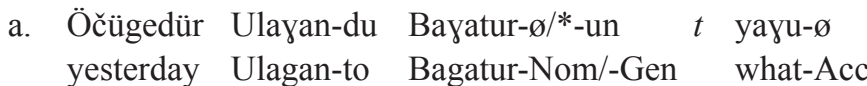 ügkü-gsen-bui?
give-Past.Adn-Q
'[Q to Ulagan, Bagatur gave what $t]$.'
$\begin{array}{lll}\text { b. Öčügedür Ulayan-du Bayatur- } \varnothing / *-u n & t \text { nom- } \varnothing \\ \text { yesterday Ulagan-to } & \text { Bagatur-Nom/-Gen } & \text { book-Acc }\end{array}$ ügkü-gsen-siu.
give-Past.Adn-Prt
'To Ulagan, Bagatur gave a book $t$.'

The data from (27) to (34) thus clearly indicate that a goal phrase cannot license genitive subjects in Mongolian.

Let us then turn to examples with long distance scrambling. Consider the examples in (35). (35a) contains an embedded complement clause whose predicate is in the adnominal form, and the sentence is ungrammatical with a genitive subject. However, when the object of the embedded clause is moved to the sentence-initial position by scrambling, the sentence becomes grammatical, as shown in (35b).
a. Bayatur- $\varnothing$ [Ulayan- $\varnothing / *-u$
ene nom-i
Bagatur-Nom Ulagan-Nom/-Gen this book-Acc
biči-gsen gejü] boduju bayina.
write-Past.Adn that think be.Pres.Con
'Bagatur thinks that Ulagan wrote this book.'
b. Ene nom-i Bayatur- $\varnothing$ [Ulayan- $\varnothing /-u$
this book-Acc Bagatur-Nom Ulagan-Nom/-Gen
biči-gsen gejü] boduju bayina.
write-Past.Adn that think be.Pres.Con
'This book, Bagatur thinks that Ulagan wrote $t$.'

Note that scrambled objects license genitive subjects in complement clauses in general, as shown in (36) and (37). In (36), the matrix predicate is kelejei 'say-Past.Con,' and in (37), it is sonus-čai 'hear-Past.Con.'
a. Bayatur- $\varnothing$
[Ulayan-ø/*-u
ene nom-i
Bagatur-Nom Ulagan-Nom/-Gen this book-Acc
biči-gsen gejü] kele-jei.
write-Past.Adn that say-Past.Con
'Bagatur said that Ulagan bought this book.' 
b. Ene nom-i [Bayatur- $\varnothing$ Ulayan- $\varnothing /-\mathrm{u} \quad t$

this book-Acc Bagatur-Nom Ulagan-Nom/-Gen

biči-gsen gejü] kele-jei.

write-Past.Adn that say-Past.Con

'This book, Bagatur said that Ulagan wrote $t$. '

a. Bayatur- $\varnothing$ [Ulayan- $\varnothing / *-u$ ene nom-i

Bagatur-Nom Ulagan-Nom/-Gen this book-Acc

biči-gsen gejü] Batu-eče sonus-čai.

write-Past.Adn that Batu-from hear-Past.Con

'Bagatur heard from Batu that Ulagan wrote this book.'

b. Ene nom-i Bayatur-ø [Ulayan-ø/-u $t$

this book-Acc Bagatur-Nom Ulagan-Nom/-Gen

biči-gsen gejü] Batu-eče sonus-čai.

write-Past.Adn that Batu-from hear-Past.Con

'This book, Bagatur heard from Batu that Ulagan wrote $t$.'

Note also that a goal phrase that has undergone long distance scrambling cannot license a genitive subject, as shown in (38).
a. Bayatur- $\varnothing$
[Ulayan-ø/*-u
Tookyo-du ire-gsen
Bagatur-Nom Ulagan-Nom/-Gen Tokyo-to come-Past.Adn gejü] kele-jei.
that say-Past.Con
'Bagatur said that Ulagan came to Tokyo.'
b. Tookyo-du Bayatur- $\varnothing \quad$ [Ulayan- $\varnothing /{ }^{*}-\mathrm{u} \quad t$ ire-gsen
Tokyo-to Bagatur-Nom Ulagan-Nom/-Gen come-Past.Adn that kele-jei.
gejü] say-Past.Con
'To Tokyo, Bagatur said that Ulagan came $t$.'

Let us then turn to examples with more embeddings to see if the same saving effect is observed. Consider the examples in (39). (39a) contains two embeddings, and the sentence is ungrammatical when the subject in the most deeply embedded clause is genitive. However, when the object of the clause is moved to the sentence-initial position, the sentence becomes grammatical, as shown in (39b).
(39)
a. Batu- $\varnothing$
Bayatur- $\varnothing$
[Ulayan- $\varnothing / *-u$
ene nom-i
Batu-Nom Bagatur-Nom Ulagan-Nom/-Gen this book-Acc qudaldun-abu-ysan gejü] kele-gsen gejü bodu-jai. buy-take-Past.Adn that say-Past.Adn that think-Past.Con 'Batu thought that Bagatur said that Ulagan bought this book.' 
b. Ene nom-i Batu- $\varnothing$ Bayatur- $\varnothing \quad$ [Ulayan- $\varnothing /-u \quad t$ this book-Acc Batu-Nom Bagatur-Nom Ulagan-Nom/-Gen qudaldun-abu-ysan gejü] kele-gsen gejü bodu-jai. buy-take-Past.Adn that say-Past.Adn that think-Past.Con 'This book, Batu thought that Bagatur said that Ulagan bought $t$ ''

The saving effect is also observed in more complex cases. Let us consider the examples in (40). (40a) contains two embeddings, and the sentence is ungrammatical when the subject in the intermediate clause is genitive. (40b) shows that the sentence becomes grammatical when the object of the most deeply embedded clause is scrambled to the sentence-initial position.

a. Batu- $\varnothing$ [Bayatur- $\varnothing / *-$ Un Ulayan- $\varnothing$ ene nom-i Batu-Nom Bagatur-Nom/-Gen Ulagan-Nom this book-Acc qudaldun-abu-ysan gejü kele-gsen gejü] bodu-jai.

buy-take-Past.Adn that say-Past.Adn that think-Past.Con 'Batu thought that Bagatur said that Ulagan bought this book.'

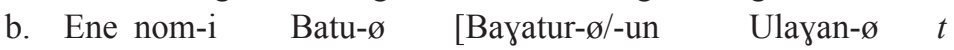
this book-Acc Batu-Nom Bagatur-Nom/-Gen Ulagan-Nom qudaldun-abu-ysan gejü kele-gsen gejü] bodu-jai. buy-take-Past.Adn that say-past.Adn that think-Past.Con 'This book, Batu thought that Bagatur said that Ulagan bought $t$.'

However, it is not always the case that scrambled objects show the saving effect for genitive subjects. Let us consider the examples in (41).

$\begin{array}{llll}\text { a. Batu- } \varnothing & \text { Bayatur- } \varnothing / *-\text {-un } & \text { Ulayan- } \varnothing & \text { nom-un } \\ & \text { Batu-Nom } & \text { Bagatur-Nom/-Gen } & \text { Ulagan-Nom book-Gen }\end{array}$ sang-eče ali nom-i jigele-gsen-i

library-from which book-Acc check.out-Past.Adn-Acc medekü gejü boduju bayina.

know.Pres.Adn that think be.Pres.Con

'Batu thinks that Bagatur knows [Q Ulagan checked out which book from the library].'

b. Batu- $\varnothing$ ali nom-i Bayatur- $\varnothing / *$-un Ulayan- $\varnothing$

Batu-Nom which book-Acc Bagatur-Nom/-Gen Ulagan-Nom nom-un sang-eče $t$ jigele-gsen-i

book-Gen library-from check.out-Past.Adn-Acc

medekü gejü boduju bayina.

know.Pres.Adn that think be.Pres.Con 
'Batu thinks that which book, Bagatur knows [Q Ulagan checked out $t$ from the library].'

c. Ali nom-i Batu- $\varnothing$ Bayatur- $\varnothing / *$-un Ulayan- $\varnothing$ which book-Acc Batu-Nom Bagatur-Nom/-Gen Ulagan-Nom nom-un sang-eče $t$ jigele-gsen-i book-Gen library-from check.out-Past.Adn-Acc medekü gejü boduju bayina. know.Pres.Adn that think be.Pres.Con 'Which book, Batu thinks that Bagatur knows [Q Ulagan checked out $t$ from the library].'

In (41a), the most deeply embedded clause is an indirect wh-question containing an object wh-phrase, and the sentence is ungrammatical when the subject of the intermediate clause is genitive. In (41b), the object whphrase is scrambled to the initial position of the intermediate clause, and the sentence is ungrammatical with the genitive subject in the intermediate clause. (41c) shows that the same is true when the object wh-phrase is scrambled to the sentence-initial position. ${ }^{3}$

3 Note in passing that the subject of the embedded clause can be genitive, whether or not the object wh-phrase undergoes clause-bound scrambling, as shown in (i) and (ii).
(i) Bayatur-ø
[Ulayan-ø/-u
nom-un sang-eče ali
Bagatur-Nom Ulagan-Nom/-Gen nom-i jigele-gsen-i] mede-ne.
book-Acc check.out-Past.Adn-Acc know-Pres.Con
'Bagatur knows [Q Ulagan checked out which book from the library].'
(ii) Bayatur- $\varnothing$ ali nom-i [Ulayan- $\varnothing /-u$ nom-un
Bagatur-Nom which book-Acc Ulagan-Nom/-Gen book-Gen
sang-eče jigele-gsen-i] mede-ne.
library-from check.out-Past.Adn-Acc know-Pres.Con
'Bagatur knows [Q which book, Ulagan checked out $t$ from the library].'

The fact that (i) with a genitive subject is grammatical seems to suggest that an indirect question in the complement position of a predicate in Mongolian, marked accusative, is headed by a covert nominal element, which corresponds to the nominalizer no in Japanese, as shown in (iii).
(iii) Taroo-wa [asu
kurasu-ga/-no
nai] no-o shittei-ru. Taro-Top tomorrow class-Nom/-Gen be.not Nml-Acc know-Pres 'Taro knows (the fact) that there will be no class tomorrow.'

If this is true, the fact that (i) allows a genitive subject in an indirect question in Mongolian is naturally expected, as the genitive subject is in a local relationship with the adnominal form of a predicate, and a covert nominal element. 


\section{Discussion}

Newly elicited data shown above indicate that Mongolian allows genitive subjects not only in relative clauses, but also in independent clauses in which a scrambled NP c-commands the genitive subject of the clause whose predicate is in the adnominal form. Let us consider then what this finding might suggest for the theory of (Mongolian) syntax. First, given the conditions on genitive subject licensing in (15), reproduced as (42), nominal elements that contribute to genitive subject licensing in Mongolian in (42a) are not only $\mathrm{X}^{0}$ categories such as relative heads (or Ds), but also phrasal categories (XPs) such as NPs that have undergone scrambling across relevant genitive subjects.

(42) Conditions on Genitive Subject Licensing in Mongolian

a. A genitive subject must be c-commanded by a nominal element in a local domain.

b. A genitive subject must be in a local relationship with the adnominal form of a predicate.

In order to see the exact mechanism, let us reexamine the example in (22b), reproduced as (43).

(43)

Öčügedür ene nom-i Ulayan-ø/-u $t$
yesterday this book-Acc Ulagan-Nom/-Gen
qudaldun-abu-ysan-siu.
buy-take-Past.Adn-Prt
'This book, Ulagan bought $t$ yesterday.'

In (43), the object is moved to the position below the adverb öcügedür 'yesterday' and above the subject Ulayan 'Ulagan,' and the sentence ends with the sentence-final particle siu 'Prt.' It is plausible to assume that the particle is a functional head that takes TP. Since the scrambled object is below the sentence-initial adverb, it seems plausible to hypothesize that it has adjoined to TP rather than a projection of the particle, as shown in (44).

$$
\text { [Хр [тр Adverb Obj [тр Sub-Gen...V-T(Adn)]] X] }
$$

In (44), the scrambled object locally c-commands the genitive subject, which is also in a local relationship with the adnominal form of the predicate. Since the scrambled object is the only nominal element that locally c-commands the genitive subject, it seems correct to conclude that it satisfies the condition in (42a). At the same time, it is an XP, not a head. Therefore, nominal elements that contribute to genitive subject licensing in Mongolian are not only $\mathrm{X}^{0}$ categories, but also phrasal categories 
that have undergone scrambling across relevant genitive subjects.

Note here that phrasal categories that contribute to genitive subject licensing in Mongolian are limited to NPs, as shown by the example in (30a), reproduced as (45), where a scrambled PP does not save the genitive subject.

$$
\begin{aligned}
& \text { Öčügedür Tookyo-du ken-ø/*-u } t \text { ire-gsen-bui? } \\
& \text { yesterday Tokyo-to who-Nom/-Gen } \\
& \text { 'To Tokyo, who came } t \text { yesterday?' }
\end{aligned}
$$

This is expected, as the relevant nominal element Tookyo 'Tokyo' is a complement of the postposition $d u$ 'to,' so that it cannot c-command the genitive subject.

Let us then consider what the proposed licensing mechanism might suggest for more complex cases such as (35b), reproduced as (46).
Ene nom-i Bayatur- $\varnothing \quad$ [Ulayan- $\varnothing /-u \quad t$ biči-gsen
this book-Acc Bagatur-Nom Ulagan-Nom/-Gen write-Past.Adn gejü] boduju bayina.
that think be.Pres.Con

'This book, Bagatur thinks that Ulagan wrote $t$.'

(46) has one embedding, and the object in the embedded clause undergoes long distance scrambling, targeting the sentence-initial position. The relevant structure of (46) is shown in (47).

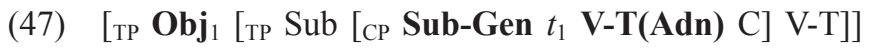

In (47), while the genitive subject in the embedded clause is in a local relationship with the adnominal form of the predicate, it is not "locally" c-commanded by the scrambled object, as they are separated by a clause boundary. Also, since the scrambled object is not a scope-taking element, unlike a wh-phrase, it need not return to its original position by LF undoing (Saito (1989)). Furthermore, if long distance scrambling must be undone (in Mongolian), the scrambled object will return to its base-position $(t)$, where it cannot c-command the genitive subject. Nonetheless, (46) is grammatical with the genitive subject in the embedded clause. To see what is actually taking place in (46), it is necessary to examine the derivation in which the object has undergone scrambling. (48) is a rough representation of the derivation involved in (46).

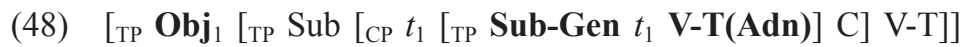
If movement proceeds in a phase-by-phase fashion (Chomsky $(2000,2001)$ ), the object reaches the final destination stopping at the specifier position of $\mathrm{C}$, a phase head, on the way. (For the sake of simplicity, we ignore $v$ as a phase head in this paper.) Suppose that the scrambled object stays at 
the surface position at $\mathrm{LF}^{4}$ Then, it will head an $\mathrm{A}^{\prime}$-chain, or an operatorvariable chain, as shown in (49). See Chomsky (1991) for legitimate LF objects, one of which is an operator-variable chain.

(49) $\left(\mathrm{Obj}_{1}, t_{\mathrm{Obj} 1}\right)$

Note here that in discussing the licensing mechanism of deep genitive subjects, we hypothesized, revising Maki et al.'s (2011) original idea, that the relevant Comp in the binding path from the relative head to its gap may host the feature $[+\mathrm{N}]$ inherited from the relative head, and can function as a licensor for genitive subjects, based on Rizzi's (1990) idea about feature specifications on functional categories. Since scrambling leaves a trace, which is c-commanded by its antecedent, it is not implausible to assume that the same sort of mechanism is involved in cases such as (46). We then claim that a relation is established between a scrambled object and its gap by c-commanding, and the relevant Comp in the binding path from the scrambled object to its gap hosts the feature $[+\mathrm{N}]$ inherited from the object, and functions as a licensor for the genitive subject at issue. In (50), the relevant Comp in the binding path is circled.

(50) $\quad$ [тр Obj ${ }_{1}\left[\right.$ те Sub [ст $t_{1}$ [тр Sub-Gen $t_{1}$ V-T(Adn)]CD V-T] $]$

Note that the local configuration with the genitive subject in the embedded clause in (50) will look like (51).

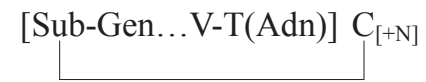

This is exactly parallel to the configurations in (11) and (14), reproduced as (52) and (53), for the sentences in (2) and (7), reproduced as (54) and (55), where the nominal feature is in a local relationship with the genitive subject.

(52)

(53)

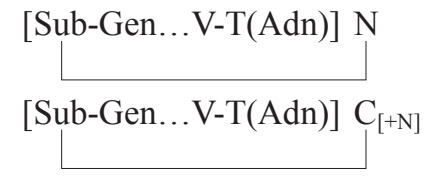

$(=(11))$

$(=(14))$

${ }^{4}$ One might argue that long distance scrambling is undone at LF in Mongolian, and the scrambled object in (46) moves back to its original position, and then, moves up again to a position where it can c-command the genitive subject at LF. We will not pursue this possibility in this paper, however, because it is not clear that the object that has moved back to its base-position targets the specifier position of $\mathrm{C}$ in the embedded clause, rather than the other positions. 
(54)

Öčügedür Ulayan-ø/-u

yesterday Ulagan-Nom/-Gen

nom-bol ene nom.

book-Top this book

'The book which Ulagan bought yesterday is this book.'

(55)

Bayatur- $\varnothing \quad$ Ulayan-u $t_{1}$ qudaldun-ab-ysan/*-ab-čai $t$ qudaldun-abu-ysan/*-ab-čai

buy-take-Past.Adn/-take-Past.Con

Bagatur-Nom Ulagan-Gen buy-take-Past.Adn/-take-Past.Con

gejü bodu-ysan nom ${ }_{1}$-bol ene nom.

that think-Past.Adn book-Top this book

'The book which Bagatur thought [that Ulagan bought $t$ ] is this book.'

In (50), the genitive subject is c-commanded by the nominal element in $\mathrm{C}_{[+\mathrm{N}]}$ in a local domain, and is in a local relationship with the adnominal form of the predicate, just as in (54) and (55), satisfying the conditions in (42).

Let us then consider what the proposed licensing mechanism might suggest for more complex cases such as (40b), reproduced as (56).

(56)

Ene nom-i Batu- $\varnothing$ [Bayatur-ø/-un
this book-Acc Batu-Nom Bagatur-Nom/-Gen Ulagan-Nom $t$
qudaldun-abu-ysan gejü kele-gsen gejü] bodu-jai.
buy-take-Past.Adn that say-past.Adn that think-Past.Con
'This book, Batu thought that Bagatur said that Ulagan bought $t$.

$(=(40 \mathrm{~b}))$

(56) has two embeddings, and the object in the most deeply embedded clause undergoes long distance scrambling, targeting the sentence-initial position. What is special about (56) is the fact that the genitive subject at issue is in the intermediate clause. The relevant structure of (56) is shown in (57).

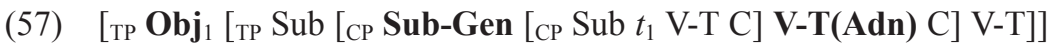
In (57), while the genitive subject in the intermediate clause is in a local relationship with the adnominal form of the predicate, it is not "locally" ccommanded by the scrambled object, as it is one clause up. However, just as in (46), a relation is established between the scrambled object and its gap by c-commanding, and the relevant Comp in the binding path from the scrambled object to its gap hosts the feature $[+\mathrm{N}]$ inherited from the object, and functions as a licensor for the genitive subject at issue. In (58), the relevant Comp in the binding path is circled.

(58) [те Obj $_{1}$ [тP $_{\text {TP }}$ [CP Sub-Gen [CP Sub $t_{1}$ V-T C] V-T(Adn)(C) V-T]] Note that the local configuration with the genitive subject in the intermedi- 
ate clause in (58) will look like (59).

[Sub-Gen...V-T(Adn)] $\mathrm{C}_{[+\mathrm{N}]}$

This is exactly parallel to the configurations in $(51)-(53)$, where the nominal feature is in a local relationship with the genitive subject. Therefore, in (56), the genitive subject is c-commanded by the nominal element in $\mathrm{C}_{[+\mathrm{N}]}$ in a local domain, and is in a local relationship with the adnominal form of the predicate, satisfying the conditions in (42).

The above argument shows that an $\mathrm{A}^{\prime}$-chain may license genitive subjects in Mongolian. Let us examine whether this is general enough on the basis of some constructions that involve $\mathrm{A}^{\prime}$-chain formation in Mongolian. First, let us consider the cleft construction in Mongolian, which is examined in detail by Bao (2014a). Consider the examples in (60) and (61). (61) is formed by clefting the object in (60).

(60) Ulayan-ø ene nom-i qudaldun-ab-čai.

Ulagan-Nom this book-Acc buy-take-Past.Con

'Ulagan bought this book.'

(61) Ulayan-ø $t$ qudaldun-abu-ysan-ni-bol ene nom-i.

Ulagan-Nom buy-take-Past.Adn-PoP3-Top this book-Acc

'It is this book that Ulagan bought.'

Note that as (61) shows, clefting in Mongolian attaches the 3rd person possessive pronoun $n i$ 'PoP3' to the adnominal form of the predicate, which roughly corresponds to the nominalizer no that is also attached to the predicate in the cleft construction in Japanese, as shown in (62).

Note also that the cleft construction in Mongolian does not end with a copula, unlike Japanese.

Let us now examine whether clefting can license genitive subjects in Mongolian. Bao (2014a) provides data that show that it can. Bao's (2014a) data, which are slightly edited, are shown in (63)-(67)..$^{5}$

\footnotetext{
5 Note that the cleft construction in Mongolian involves a complication. This is because clefting in Mongolian attaches the 3rd person possessive pronoun $n i$ 'PoP3' to the adnominal form of the predicate, which functions as a nominal element that can license genitive subjects. Therefore, in spite of the prediction that a clefted PP cannot license genitive subjects, it can, actually, as shown in (i).
} 
(63) Ulayan-u $t$ qudaldun-abu-ysan-ni-bol ene nom-i.

Ulagan-Gen buy-take-Past.Adn-PoP3-Top this book-Acc

'It is this book that Uragan bought.'

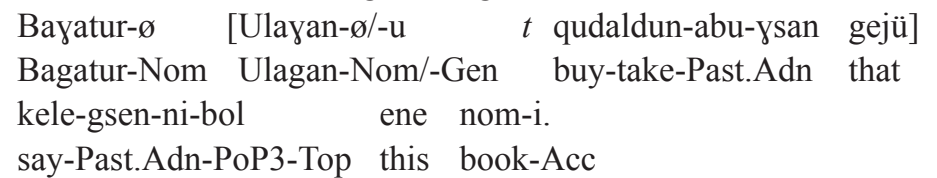

'It is this book that Bagatur said that Ulagan bought.'
Bayatur- $\varnothing /-u n$ [Ulayan- $\varnothing \quad t$ qudaldun-abu- $y$ san gejü]
Bagatur-Nom/-Gen Ulagan-Nom buy-take-Past.Adn that
kele-gsen-ni-bol ene nom-i.
say-Past.Adn-PoP3-Top this book-Acc
'It is this book that Bagatur said that Ulagan bought.'

(66) Batu- $\varnothing \quad\left[\right.$ Bayatur- $\varnothing /-u n \quad\left[\right.$ Ulayan- $\varnothing \quad t$ qudalduju-abu- ${ }^{-}$san

Batu-Nom Bagatur-Nom/-Gen Ulagan-Nom buy-take-Past.Adn gejü] kele-gsen gejü] bodu-ysan-ni-bol ene nom-i.

that say-Past.Adn that think-Past.Adn-PoP3-Top this book-Acc 'It is this book that Batu thought that Bagatur said that Ulagan bought.'

In (63), the subject of the cleft sentence is marked genitive, in (64), the subject of the embedded clause is marked genitive, in (65), the subject of the matrix clause is marked genitive, and in (66), the subject of the intermediate clause is marked genitive. These are all expected, if the cleft construction involves movement of a null operator that corresponds to the clefted element to the specifier position of the highest CP. The relevant structure for the four examples is shown in (67).

$\begin{array}{lll}\text { (i) Ulayan-ø/-u } & t \text { ire-gsen-ni-bol } & \text { Tokyo-eče. } \\ \text { Ulagan-Nom/-Gen } & \text { come-Past.Adn-PoP3-Top } & \text { Tokyo-from } \\ \text { 'It is from Tokyo that Ulagan came.' } & \end{array}$

There is a further complication for PP clefting in Mongolian. The proposed analysis would predict that long distance clefting of a PP cannot license genitive subjects. However, long distance clefting of a PP, not an NP, is not allowed, whether the relevant subject is marked genitive or not, as shown by the contrast between (ii) and the example in (64).
(ii) *Bayatur- $\varnothing \quad$ [Ulayan- $\varnothing /-u \quad t$ ire-gsen gejü]
Bagatur-Nom Ulagan-Nom/-Gen come-Past.Adn that
kele-gsen-ni-bol Tokyo-eče.
say-Past.Adn-PoP3-Top Tokyo-from
'It is from Tokyo that Bagatur said [that Ulagan came $t]$.'

(ii) is ungrammatical with the nominative subject in the embedded clause. We will not go into detail on this issue, as it is beyond the scope of this paper. 
(67)

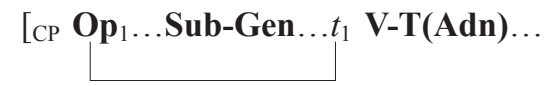

Then, the operator with a nominal feature may locally c-command the genitive subject, which is also in a local relationship with the adnominal form of the predicate. Note that even if the operator itself does not locally c-command the genitive subject, the $\mathrm{A}^{\prime}$-chain headed by the operator contributes to licensing of the genitive subject, because there is a head $\mathrm{C}$ with a nominal feature on the path from the operator to the trace in the $\mathrm{A}^{\prime}$-chain which locally c-commands the genitive subject, as argued above.

Second, let us turn to the comparative construction in Mongolian, another construction that involves $A^{\prime}$-chain formation. See Watanabe (1996) for data that show that the comparative construction in Japanese allows a genitive subject. Chomsky (1977) claims that comparative formation involves movement of an operator. If the operator in the comparative construction in Mongolian bears nominality, it is predicted that the construction allows genitive subjects. Let us examine if this prediction is correct. A typical example of the comparative construction in Mongolian is shown in (68).
(68) Batu- $\varnothing$ [Ulayan- $\varnothing$ ungši-ysan eče] olan nom-ø Batu-Nom Ulagan-Nom read-Past.Adn than many book-Acc ungši-jai.
read-Past.Con

'Batu read more books than Ulagan read.'

In (68), the comparative clause in the brackets has the adnominal form of the predicate, and the subject is nominative. Let us now see if the subject of a comparative clause may be generally allowed to have a genitive subject. Consider the examples in (69)-(72). (69)-(71) are from Bao (2014a) with slight editing.

(69) Batu- $\varnothing$ [Ulayan-ø/-u ungši-ysan eče] olan nom-ø Batu-Nom Ulagan-Nom/-Gen read-Past.Adn than many book-Acc ungši-jai.

read-Past.Con

'Batu read more books than Ulagan read.'

(70) Batu- $\varnothing$ Bayatur- $\varnothing \quad$ [Ulayan- $\varnothing /-u \quad$ ungši-ysan gejü] Batu-Nom Bagatur-Nom Ulagan-Nom/-Gen read-Past.Adn that bodu-ysan eče olan nom-ø ungši-jai. think-Past.Adn than many book-Acc read-Past.Con 'Batu read more books than Bagatur thought that Ulagan read.' 
(71) Batu- $\varnothing \quad$ [Bayatur- $\varnothing /-u n \quad$ Ulayan- $\varnothing \quad$ ungši-ysan gejü Batu-Nom Bagatur-Nom/-Gen Ulagan-Nom read-Past.Adn that bodu-ysan] eče olan nom-ø ungši-jai. think-Past.Adn than many book-Acc read-Past.Con 'Batu read more books than Bagatur thought that Ulagan read.'

(72) Batu- $\varnothing \quad$ Gerel- $\varnothing \quad$ [Bayatur- $\varnothing /-$ un Ulayan- $\varnothing$ Batu-Nom Gerel-Nom Bagatur-Nom/-Gen Ulagan-Nom ungši-ysan gejü kele-gsen gejü] bodu-ysan eče read-Past.Adn that say-Past.Adn that think-Past.Adn than olan nom- $\varnothing$ ungši-jai. many book-Acc read-Past.Con

'Batu read more books than Gerel thought that Bagatur said that Ulagan read.'

In (69), the subject of the comparative clause can be marked genitive, in (70), the subject of the embedded clause can be marked genitive, in (71), the subject of the matrix clause can be marked genitive, and in (72), the subject of the intermediate clause can be marked genitive. Again, these are all expected, if the comparative construction involves movement of a null operator to the specifier position of the highest $\mathrm{CP}$, just as in the case of the cleft construction.

Let us then turn to topicalization in Mongolian, which is investigated by Bao (2014b). Consider the examples in (73) and (74). (74) is formed by topicalizing the object in (73). The topic marker in Mongolian is bol 'Top.'

$$
\begin{aligned}
& \text { Nidunun Ulayan-ø ene nom-i biči-jei. } \\
& \text { last.year Ulagan-Nom this book-Acc write-Past.Con } \\
& \text { 'Ulagan wrote this book last year.' } \\
& \text { Ene nom-i-bol nidunun Ulayan- } \varnothing \quad t \text { biči-jei. } \\
& \text { this book-Acc-Top last.year Ulagan-Nom } \quad \text { write-Past.Con } \\
& \text { 'This book, Ulagan wrote } t \text { last year.' }
\end{aligned}
$$

Note that in (74), the topicalized phrase has a topic reading as well as a contrastive meaning. In this paper, we only focus on the topic reading.

Let us now examine whether long distance topicalization can license genitive subjects in Mongolian. First, (75) shows that a topic cannot license a genitive subject in a simple sentence, as the predicate is in the conclusive form.

$$
\begin{aligned}
& \text { (75) *Ene nom-i-bol nidunun Ulayan-u } t \text { biči-jei. } \\
& \text { this book-Acc-Top last.year Ulagan-Gen } \\
& \text { 'This book, Ulagan wrote } t \text { last year.' }
\end{aligned}
$$


However, (75) becomes perfect when the sentence is followed by the yes/ no-question particle $u$ ' 'YNQ,' which requires the preceding predicate to be in the adnominal form, as shown in (76).

(76) Ene nom-i-bol nidunun Ulayan-u $t$ biči-gsen-uu?

this book-Acc-Top last.year Ulagan-Gen write-Past.Adn-YNQ 'This book, did Ulagan write $t$ last year?'

Second, a topic that has undergone long distance movement can license a genitive subject in the most deeply embedded clause, as shown in (77), and a genitive subject in the intermediate clause, as shown in (78).

(77) Ene nom-i-bol Batu- $\varnothing$ Bayatur- $\varnothing \quad[$ Ulayan- $\varnothing /-u \quad t$ this book-Acc-Top Batu-Nom Bagatur-Nom Ulagan-Nom/-Gen biči-gsen gejü] kele-gsen gejü bodu-jai. write-Past.Adn that say-Past.Adn that think-Past.Con 'This book, Batu thought that Bagatur said that Ulagan wrote $t$.'

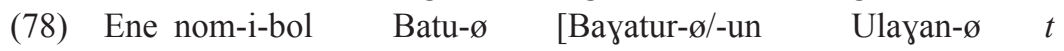
this book-Acc-Top Batu-Nom Bagatur-Nom/-Gen Ulagan-Nom biči-gsen gejü kele-gsen gejü] bodu-jai. write-Past.Adn that say-Past.Adn that think-Past.Con 'This book, Batu thought that Bagatur said that Ulagan wrote $t$.'

However, a topicalized PP cannot license a genitive subject, as shown in (79).

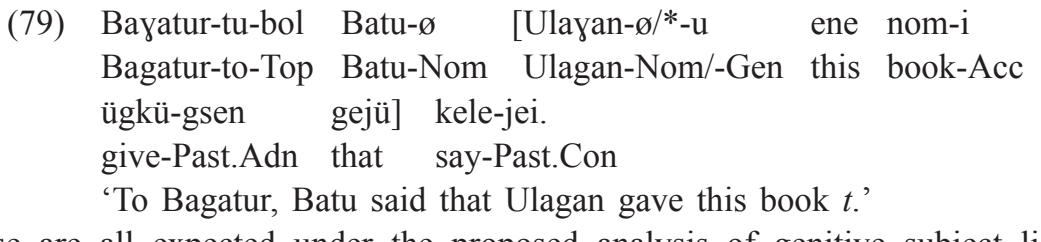
These are all expected under the proposed analysis of genitive subject licensing in Mongolian.

Let us finally consider relative clauses again. Just as in the constructions examined above, a genitive subject is allowed in the intermediate clause within a relative clause, as shown in (80).
(80)
Batu- $\varnothing$
[Bayatur-ø/-un
Ulayan-ø
$t$ biči-gsen
gejü kele-gsen
gejü] bodu-ysan
write-Past.Adn
that say-Past.Adn that think-Past.Adn book-Top this book
'The book which Batu thought that Bagatur said that Ulagan wrote is this book.'

In (80), the genitive subject in the intermediate clause is not locally ccommanded by the nominal head nom 'book.' Even if one assumes that 
relativization in Mongolian involves null operator movement, the operator moved to the highest specifier of CP does not locally c-command the genitive subject, either. What is then relevant to licensing of the genitive subject in this case is the nominal path from the relative head/the null operator to the trace, which contains a Comp with a nominal feature, which in turn locally c-commands the genitive subject. Therefore, the fact that (80) allows a genitive subject in the intermediate clause within a relative clause is again expected under the proposed analysis of genitive subject licensing in Mongolian.

The second thing which the finding of this paper might suggest for the theory of (Mongolian) syntax is the fact that the conditions in (42) should apply at LF, which in turn suggests that scrambling does not involve obligatory LF undoing, unlike Bošković and Takahashi's (1998) proposal.

We have seen above that a scrambled NP, if it is a wh-phrase, cannot license a genitive subject when it takes scope at the clause which does not contain the genitive subject, as shown in (41b), reproduced as (81).
Batu- $\varnothing$ ali
nom-i
Bayatur-ø/*-un
Ulayan-ø
Batu-Nom which book-Acc Bagatur-Nom/-Gen
Ulagan-Nom
nom-un sang-eče $t$ jigele-gsen-i medekü
book-Gen library-from check.out-Past.Adn-Acc know.Pres.Adn gejü boduju bayina.
that think be.Pres.Con
'Batu thinks that which book, Bagatur knows [Q Ulagan checked out $t$ from the library].'

Suppose that the conditions in (42) apply at the level of representation traditionally called "S-Structure," which we call "the structure before LF" in this paper. $^{6}$ Then, (81) should be grammatical with the genitive subject

\footnotetext{
6 The theoretical framework presupposed in this paper is generative grammar originally advocated by Chomsky (1957). Chomsky (1965) lays out the so-called Standard Theory, which posits two different representations for a sentence called Deep Structure (D-Structure) and Surface Structure (S-Structure), which are related by the operation called transformation. Then, the representation at Surface Structure is fed into the meaning component called Logical Form (LF) and the sound component called Phonetic Form (PF). Chomsky (1995) attempts to eliminate the two representations from the theory of grammar, suggesting the so-called Minimalist Program, in which a derivation of a sentence diverges to PF and LF at the point called Spell-Out, which corresponds to SStructure in the framework before Minimalist Program. In this paper, for expository purposes, we use the terms S-Structure and the structure before LF, which are identical to the structure at the point of Spell-Out in the terms of Minimalist Program.
} 
Bayatur-un 'Bagatur-Gen' in the intermediate clause, because the wh-phrase ali nom- $i$ 'which book-Acc' locally c-commands the genitive subject at the structure before LF, and at the same time, the genitive subject is in a local relationship with the adnominal form of the predicate medekü 'know.Pres. Adn.' When genitive subject licensing is done at the structure before LF, the fronted wh-phrase may move back to its original position for scope taking at LF by LF undoing. Then, (81) would be incorrectly predicted to be grammatical with a genitive subject in the intermediate clause. However, the fact that (81) with a genitive subject in the intermediate clause is ungrammatical along with the fact that the fronted wh-phrase needs to be in the clause in which it is base-generated for scope taking, suggests that the conditions in (42) should not apply at the structure before LF, but at LF, when scrambling has been undone.

Let us assume then that it is correct to hypothesize that the conditions in (42) apply at LF, and consider the two major approaches to scrambling. Saito (1985), among others, assumes that scrambling is a syntactic movement operation, so that an element undergoes upward movement by scrambling in overt syntax, and Saito (1989) claims that scrambling can be undone at LF, when it is required by some factors such as scope taking by a wh-phrase. Bošković and Takahashi (1998) claim that LF undoing is the main property of scrambling, stating that "scrambled sentences involve obligatory LF movement of arguments base-generated in non- $\theta$-positions to the positions where they receive $\theta$-roles (p. 363)."

In the above discussion, we have confirmed that the conditions in (42) apply at LF. If Bošković and Takahashi's (1998) proposal is correct, a scrambled object must move back to its base-position ( $\theta$-position) at LF for $\theta$-theoretic reasons. Then, the scrambled object in $(39 b) /(46)$, for example, reproduced as (82), needs to return to its base-position at LF, and its LF structure would be identical to the sentence in (39a), reproduced as (83).

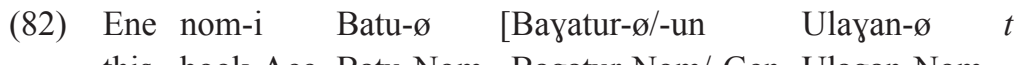
this book-Acc Batu-Nom Bagatur-Nom/-Gen Ulagan-Nom qudaldun-abu-ysan gejü kele-gsen gejü] bodu-jai. buy-take-Past.Adn that say-Past.Adn that think-Past.Con 'This book, Batu thought that Bagatur said that Ulagan bought $t$.'
(83) Batu- $\varnothing$ Bayatur- $\varnothing \quad$ [Ulayan- $\varnothing /{ }^{*}-\mathrm{u}$ ene nom-i Batu-Nom Bagatur-Nom Ulagan-Nom/-Gen this book-Acc qudaldun-abu-ysan gejü] kele-gsen gejü bodu-jai. buy-take-Past.Adn that say-Past.Adn that think-Past.Con


'Batu thought that Bagatur said that Ulagan bought this book.'

Since the conditions in (42) apply at LF, it would be incorrectly predicted that the genitive subject in (82) is not licensed, because it is not locally c-commanded by a relevant nominal element. Therefore, it is safe to conclude that at least in Mongolian, scrambled sentences do not involve obligatory LF movement of arguments base-generated in non- $\theta$-positions to the positions where they receive $\theta$-roles, contrary to Bošković and Takahashi's (1998) claim.

The third thing which the finding of this paper might suggest for the theory of (Mongolian) syntax is related to the mechanism of genitive subject licensing in Japanese. We have seen in this paper that Mongolian allows long distance genitive subject licensing. However, Japanese does not, as shown by examples such as (84) and (85).

(84) Kono hon-o Taroo-ga [kyonen Hanako-ga/*-no $t$

this book-Acc Taro-Nom last.year Hanako-Nom/-Gen

kai-ta to] it-ta.

write-Past that say-Past

'This book, Taro said that Hanako wrote $t$ last year.'
Taroo-ga [kyonen Hanako-ga/*-no $t$ kai-ta
to] it-ta
Taro-Nom last.year Hanako-Nom/-Gen write-Past that say-Past hon-wa kono book desu.
book-Top this hon be.Pres
'The book which Taro said that Hanako wrote $t$ last year is this book.'

The question that immediately suggests itself is what factor distinguishes the two languages. One of the crucial differences between the two languages is the fact that in Mongolian, a [-Q] Comp can be preceded by the adnominal form of a predicate, which crucially contributes to genitive subject licensing in this language, but in Japanese, a [-Q] Comp cannot be preceded by the adnominal form of a predicate, which is evidenced by data from old Japanese. This is because while in modern Japanese, there is no morphological distinction between the conclusive form and the adnominal form of verbs, old Japanese had a clear morphological distinction between them. Consider the examples in (86). 
(86)
a. ...ari-keru mewarawa-namu, kono uta-o yome-ru. be-Past.Adn girl-Foc this poem-Acc read-Perf '...the girl who was there read this poem'
(Tosa Nikki $(028-01 / 02))^{7}$
b. ...Taketori-no-okina to iu mono-ø ari-keri. Taketori-no-okina that say man-Nom be-Past.Con '...there was a man called Taketori-no-okina...'
(Taketori Monogatari (017-04))
like.this be-Past.Con that think '...one thinks that it was like this...'
c. ...kakumo ari-keri to omoo...

(Genji Monogatari (068-046))

(86a-c) show that a verb takes its adnominal form keru 'Past.Adn' before a nominal element, its conclusive form keri 'Past.Con' in the sentence-final position, and its conclusive form before [-Q] Comp, respectively. Although the morphological distinction between the two forms has been lost, we may assume that the distinction has been abstractly kept, following Hiraiwa (2001). Then, in Japanese, a simple relative clause, as shown in (87), has the adnominal form of a predicate, but a relative clause containing a complement clause has the conclusive form of a predicate in the complement clause.

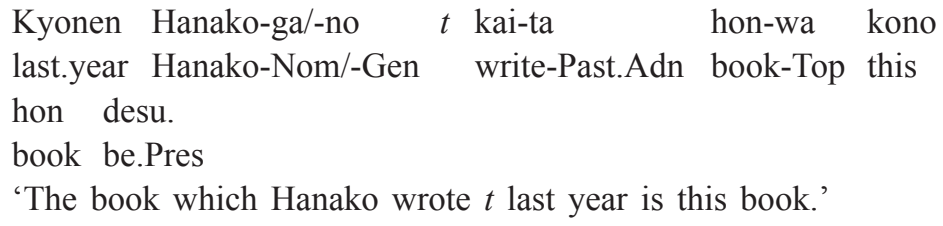

Then, the contrast between (85) with a genitive subject and (87) with a genitive subject actually follows, if one assumes that the conditions in $(42 \mathrm{a}$, b) both apply at LF in Japanese as well. This is because, only in (85), the relevant predicate for genitive subject licensing is not in the adnominal form. Thus, we propose that the conditions in (42) apply to both Mongolian and Japanese, and the differences between the two languages in terms of genitive subject licensing arise from the fact that the adnominal form

7 The old Japanese data in the text are cited from the data base Koten Soogoo Kenkyuujo (http://genji.co.jp/). The name in the parentheses indicates the name of the book, and the numbers indicate the page number, the line number, and the volume number, if any, in this order. 
of a predicate in Mongolian may occur in a broader range of environments than that in Japanese.

A note is in order, however, concerning the definition of the adnominal form in (42b) for Japanese. Kobayashi (2013) found examples such as (88), in which a genitive subject co-occurs with the continuous form, not the adnominal form, of a predicate.

(88) [Hannin-ga/-no tsukamari-shidai], renraku-o kure. criminal-Nom/-Gen capture.Cont-as.soon.as call-Acc give.Imp 'Give me a call, as soon as the criminal is captured.'

(Kobayashi (2013: 48) with slight editing) Based on (88), Kobayashi (2013) claims that Hiraiwa's (2001) adnominal form approach to genitive subject licensing is faced with a problem. Furthermore, a genitive subject may co-occur with the stem of a Sino-Japanese verb, as shown in (89).

(89) [Toshokan-de gakusee-tachi-ga/-no benkyoo-chuu-ni], yuki-ga library-in student-Pl-Nom/-Gen study.Inf-during-at snow-Nom huri-dashi-ta.

fall-start-Past

'While the students were studying in the library, it started to snow.'

Therefore, these data indicate that genitive subjects in Japanese may cooccur with a variety of inflectional forms of predicates, namely, (i) the infinitival form, (ii) the continuous form and (iii) the adnominal form.

However, the infinitival and continuous forms have a common property with the adnominal form, because these are directly followed by nominallike elements, such as chuu 'during' and shidai 'as.soon.as.' This seems to indicate that the three inflectional forms share a particular property which fits nominal elements that follow them. Therefore, we may provide a cover term for these three inflectional forms such as "the nominal form" of a predicate. If we extend "the adnominal form" in (42a) to "the nominal form" for Japanese, the conditions in (42) properly account for the relevant examples in Japanese, and at the same time, provide an adequate explanation for the differences between Japanese and Mongolian in terms of genitive subject licensing. ${ }^{8}$

Fourth, and finally, the contrast in the manner of genitive subject licens-

\footnotetext{
${ }^{8}$ Note that there is a class of sentences that may not be properly handled under the conditions in (42a, b). Consider (i), which was first discussed in Hiraiwa (2001).
} 
ing between Mongolian and Chamorro, a Malayo-Polynesian language spoken in Guam, suggests that there are (at least) two types of languages in the world with respect to genitive subject licensing, one that both requires a nominal element and the (ad)nominal form of a predicate in a local domain, and the other that only requires the latter as a result of wh-agreement. Chung (1982, 1998) and Watanabe (1996) argue that whagreement induced by wh-movement licenses genitive subjects in Chamorro and Japanese, respectively. Consider the Chamorro examples in (90) and (91), provided by Chung (1982). (90) is a declarative sentence, and (91) is a wh-interrogative sentence, involving overt wh-movement.

(i) John-wa [ame-ga/-no yam-u made] ofisu-ni i-ta. John-Top rain-Nom/-Gen stop-Pres until office-at be-Past 'John was at his office until it stopped raining.'

In (i), there is no obvious nominal element that locally c-commands the genitive subject, yet the sentence is grammatical with a genitive subject. The same is true to the Mongolian counterpart of (i), as shown in (ii).

(ii) Batu- $\varnothing \quad$ [boruyan- $\varnothing /-u$ joysu-qu boltala] alban ger-tü Batu-Nom rain-Nom/-Gen stop-Pres.Adn until office-at bai-la. be-Past.Con

'Batu was at his office until the rain stopped.'

(Maki et al. (2010: 232)) Maki and Uchibori (2008) claim that there is an invisible nominal element before made 'until.' However, Takahashi (2010) provides evidence against this claim.

There are two approaches to this issue: (i) Miyagawa $(2012,2013)$ and (ii) Harada (2002). Miyagawa $(2012,2013)$ proposes the $v$-licensing approach to the genitive that appears in a clause whose tense is controlled by the tense of the higher clause, such as (i), on the basis of its similarity in distribution to the genitive of negation in Slavic. In (i), the tense of the predicate in the made-clause is determined by the tense of the predicate in the matrix clause, and the predicate in the made-clause is unaccusative. Miyagawa $(2012,2013)$ calls this type of genitive a genitive of dependent tense (GDT), and argues that the genitive subject ame-no 'rain-Gen' is licensed by $v$ and dependent tense. Harada (2002) claims that made 'until' is used as a postposition in other cases, so that it should fundamentally take a nominal element as its complement. Therefore, in (i), the clause itself is nominalized, and has nominality, so that it functions as a nominal element, satisfying (42a). Also, the predicate is in the adnominal form, as evidenced by the example in (iii) from old Japanese.

(iii) ...chi-no nagaru-ru made...

blood-Gen flow-Adn until

'...until (he) bleeds...'

(Taketori Monogatari (036-10))

Therefore, (42b) is also satisfied in (i). Since both approaches seem plausible, we will not deicide which is correct in this paper, leaving the issue for future research. 
(90) Ha-fahan si Maria i sanhilo'-ña gi tenda. 3E.Sg-buy Unm Maria the blouse-her Loc store 'Maria bought her blouse at the store.'

(Chung (1982: 50, ex. 34b) with slight editing)

(91) Hafa f-in-ahan-ña si Maria gi tenda? what In-buy-her Unm Maria Loc store 'What did Maria buy at the store?'

(Chung (1982: 50, ex. 34a) with slight editing) In (90), the subject $h a$ ' $3 \mathrm{E} . \mathrm{Sg}$ ' is ergative, and corresponds to the NP $s i$ Maria with an unmarked case, but in (91), where the object is wh-fronted, the verb is nominalized, as indicated by insertion of the infix in into the predicate, and the genitive marker $\tilde{n} a$ 'her' is attached to the nominalized predicate. What is important with Chamorro is the fact that predicate nominalization may take place not only with an argument wh-phrase, as shown in (91), but also with an adjunct wh-phrase, as shown in (92).

(92) Taimänu malago'-mu si Pedro pära u-arekla i how want.Wh.Obl-your Unm Pedro Fut he-fix.Wh.Adj the lareta $t$ ?

car

'How do you want Pedro to fix the car?'

(Chung (1998: 211, ex. 9b) with slight editing) In (92), the fronted adjunct wh-phrase taimänu 'how' should not involve nominality, yet the genitive marker on the predicate is permitted. In Mongolian, a fronted adjunct (wh-phrase) cannot license a genitive subject, as shown in (93).

(93) Yayaqiju Bayatur-ø/*un $t$ tere terge-yi jasa-ysan-bui?
how Bagatur-Nom/-Gen that car-Acc fix-Past.Adn-Q
'[Q how, Bagatur fixed the car $t]$.'

Therefore, while in languages like Chamorro, wh-agreement nominalizes a predicate, and the nominalized predicate licenses a genitive subject in the language, in languages like Mongolian, a genitive subject needs to be licensed by a nominalized predicate and a nominal element that locally c-commands it. Hence, there are (at least) two types of languages in the world with respect to genitive subject licensing, one with the conditions in (42a, b), and the other with exclusively the condition in (42b).

\section{Conclusion}

This paper examined environments of genitive subject licensing in Mon- 
golian, and found (i) that nominal elements that contribute to genitive subject licensing in Mongolian are not only $\mathrm{X}^{0}$ categories, but also phrasal categories (XPs) such as NPs that have undergone scrambling, (ii) that genitive subject licensing takes place at LF, which in turn suggests that scrambling does not involve obligatory LF undoing, unlike Bošković and Takahashi's (1998) proposal, (iii) that the conditions on genitive subject licensing in (42) apply to both Mongolian and Japanese, and the differences between the two languages in terms of genitive subject licensing are attributed to the fact that the adnominal form of a predicate in Mongolian may occur in broader environments than that in Japanese, and (iv) that there are (at least) two types of languages in the world with respect to genitive subject licensing, one with the conditions in $(42 \mathrm{a}, \mathrm{b})$, and the other with exclusively the condition in (42b).

\section{REFERENCES}

Bao, Lina (2014a) "Mongorugo niokeru Bunretsubun no Kenkyuu: Zokukakushugo Ninka Shisutemu eno Shisa (A Study of the Cleft Construction in Mongolian: Implications to the System of Genitive Subject Licensing)," Nihongo Nihobunka Kenkyu 24, 24-35.

Bao, Lina (2014b) Nihongo to Mongorugo no Joshi nikansuru Hikaku Toogoron Kenkyuu (A Comparative Syntactic Study of Particles in Japanese and Mongolian), Doctoral dissertation, Osaka University.

Bošković, Željko and Daiko Takahashi (1998) "Scrambling and Last Resort," Linguistic Inquiry 29, 347-366.

Chomsky, Noam (1957) Syntactic Structures, Mouton, The Hague.

Chomsky, Noam (1965) Aspects of the Theory of Syntax, MIT Press, Cambridge, MA.

Chomsky, Noam (1977) “On Wh-Movement," Formal Syntax, ed. by Peter W. Culicover, Tom Wasow and Adrian Akmajian, 71-132, Academic Press, New York.

Chomsky, Noam (1991) "Some Notes on Economy of Derivation and Representation," Principles and Parameters in Comparative Grammar, ed. by Robert Freidin, 417-454, MIT Press, Cambridge, MA.

Chomsky, Noam (1995) The Minimalist Program, MIT Press, Cambridge, MA.

Chomsky, Noam (2000) "Minimalist Inquiries: The Framework," Step by Step: Essays on Minimalist Syntax in Honor of Howard Lasnik, ed. by Roger Martin, Juan Uriagereka and David Michaels, 89-151, MIT Press, Cambridge, MA.

Chomsky, Noam (2001) "Derivation by Phase," Ken Hale: A Life in Language, ed. by Michael Kenstowicz, 1-50, MIT Press, Cambridge, MA.

Chung, Sandra (1982) "Unbounded Dependencies in Chamorro Grammar," Linguistic 
Inquiry 13, 39-78.

Chung, Sandra (1998) The Design of Agreement: Evidence from Chamorro, University of Chicago Press, Chicago.

Endo, Yoshio (2007) Locality and Information Structure, John Benjamins, Amsterdam.

Harada, Naomi (2002) Licensing PF-Visible Formal Features: A Linear Algorithm and Case-Related Phenomena in PF, Doctoral dissertation, University of California, Irvine.

Harada, S.-I. (1971) "Ga-No Conversion and Ideolectal Variations in Japanese," Gengo Kenkyu 60, 25-38.

Hiraiwa, Ken (2001) "On Nominative-Genitive Conversion," MIT Working Papers in Linguistics 39: A Few from Building E39, ed. by Elena Guerzoni and Ora Matushansky, 66-125, Cambridge, MA.

Kobayashi, Yukino (2013) Japanese Case Alternations within Phase Theory, Doctoral dissertation, Sophia University.

Kuroda, Shige-Yuki (1973) "Where Epistemology, Style, and Grammar Meet: A Case Study from Japanese," Festschrift for Morris Halle, ed. by Stephen Anderson and Paul Kiparsky, 377-391, Hold, Rinehard and Winston, New York.

Maki, Hideki, Lina Bao, Wurigumula Bao, Qing-Yu Wu, Asako Uchibori, Fumikazu Niinuma, Megumi Hasebe and Juri Yoshimura (2011) "Deep Genitive in Modern Inner Mongolian," Proceedings of GLOW in ASIA VIII 2010 Universals and Variation, ed. by Ming-Le Gao, 282-288, Beijing Language and Culture University Press, Beijing.

Maki, Hideki, Lina Bao, Qing-Yu Wu, Wurigumula Bao, Asako Uchibori, Fumikazu Niinuma and Kenichi Goto (2010) "The Nominative/Genitive Alternation in Modern Mongolian," MIT Working Papers in Linguistics 61: Proceedings of the 6th Workshop on Altaic Formal Linguistics (WAFL6), ed. by Hiroki Maezawa and Azusa Yokogoshi, 229-245, Cambridge, MA.

Maki, Hideki and Asako Uchibori (2008) "Ga/No Conversion," Handbook of Japanese Linguistics, ed. by Shigeru Miyagawa and Mamoru Saito, 192-216, Oxford University Press, Oxford.

Matsuoka, Miyuki (2003) Danwaba niokeru Shuujoshi Yo no Kinoo (The Function of Yo in Discourse), Kotoba to Bunka 4, 53-69.

Miyagawa, Shigeru (1993) "Case-Checking and Minimal Link Condition," MIT Working Papers in Linguistics 19: Papers on Case and Agreement II, ed. by Colin Phillips, 213-254, Cambridge, MA.

Miyagawa, Shigeru (2011) "Genitive Subjects in Altaic and Specification of Phase," Lingua 121, 1265-1282.

Miyagawa, Shigeru (2012) Case, Argument Structure, and Word Order, Routledge, New York.

Miyagawa, Shigeru (2013) "Strong Uniformity and Ga/No Conversion," English Linguistics 30, 1-24.

Ochi, Masao (2001) "Move F and Ga/No Conversion in Japanese," Journal of East Asian Linguistics 10, 247-286. 
Rizzi, Luigi (1990) "Speculations on Verb Second," GLOW Essays for Henk van Riemsdijk, ed. by Joan Mascaro and Marina Nespor, 375-386, Foris, Dordrecht.

Saito, Mamoru (1985) Some Asymmetries in Japanese and Their Theoretical Implications, Doctoral dissertation, MIT.

Saito, Mamoru (1989) "Scrambling as Semantically Vacuous A'-Movement," Alternative Conceptions of Phrase Structure, ed. by Mark Baltin and Anthony Kroch, 182-200, University of Chicago Press, Chicago.

Saito, Mamoru (1992) "Long Distance Scrambling in Japanese," Journal of East Asian Linguistics 1, 69-118.

Takahashi, Hisako (2010) "Adverbial Clauses and Nominative/Genitive Conversion in Japanese," MIT Working Papers in Linguistics 61: Proceedings of the 6th Workshop on Altaic Formal Linguistics (WAFL6), ed. by Hiroki Maezawa and Azusa Yokogoshi, 357-371, Cambridge, MA.

Watanabe, Akira (1996) "Nominative-Genitive Conversion and Agreement in Japanese: A Cross-linguistic Perspective," Journal of East Asian Linguistics 5, $373-410$.

\title{
Primary Texts
}

Abe, Akio, Ken Akiyama, Gene Imai and Hideo Suzuki (1998) Shinpen Nihon Koten Bungaku Zenshuu (Vol. 25): Genji Monogatari (Vol. 6) (Japan Classical Literature Series: New Edition (Vol. 25): A Tale of Genji (Vol. 6)), Shogakukan, Tokyo.

Katagiri, Yoichi, Shoji Takahashi, Teisuke Fukui and Yoshiko Shimizu (1994) Shinpen Nihon Koten Bungaku Zenshuu (Vol. 12): Taketori Monogatari, Ise Monogatari, Yamato Monogatari and Heichuu Monogatari (Japan Classical Literature Series: New Edition (Vol. 12): A Tale of Taketori, A Tale of Ise, A Tale of Yamato and A Tale of Heichuu), Shogakukan, Tokyo.

Kikuchi, Yasuhiko, Tsunehisa Imuta and Masanori Kimura (1995) Shinpen Nihon Koten Bungaku Zenshuu (Vol. 13): Tosa Nikki and Kageroo Nikki (Japan Classical Literature Series: New Edition (Vol. 13): Tosa Diary and Kageroo Diary), Shogakukan, Tokyo.

[received September 16, 2015, revised and accepted January 7, 2016]

\author{
(Hideki Maki) \\ Faculty of Regional Studies \\ Gifu University \\ 1-1 Yanagido, Gifu, Gifu 501-1193 \\ e-mail:makijp@gifu-u.ac.jp
}


(Lina Bao)

Faculty of Regional Studies

Gifu University

1-1 Yanagido, Gifu, Gifu 501-1193

e-mail: baolinam_jp@yahoo.co.jp

(Wurigumula Bao)

e-mail: baowuri@yahoo.co.jp

(Megumi Hasebe)

School of General Education

Shinshu University

3-1-1 Asahi, Matsumoto, Nagano 390-8621

e-mail: haru_sakura_0713@yahoo.co.jp 